\title{
Incidence of post-harvest disease and airborne fungal spores in a vegetable market
}

\author{
UMESh B. KAKDE ${ }^{1 *}$, HeMalata U. KAKDE ${ }^{2}$ \\ ${ }^{1}$ Department of Botany, Government of Maharashtra's Ismail Yusuf College, \\ Jogeshwari (E), Mumbai, 400060 India \\ ${ }^{2}$ Shree Gauri Dutt Mittal College, Sion, Mumbai-22 India
}

\begin{abstract}
The sampling of bioaerosols has been carried out using a Rotorod sampler as well as by exposing culture plates. The screening of some common vegetables was also done for the isolation of fungi as market pathogens to study post-harvest diseases. Altogether, fifty nine fungal spore types and 78 species of 33 genera belonging to different groups were recorded respectively on the rotorod strips and on exposed Petri dishes. Many saprophytic and pathogenic fungi were found to be associated with sampled vegetables from the market. In all forty-six fungal species belonging to 26 genera were recovered from five varieties of vegetables collected from the same market. The most dominant forms of fungi were of Aspergillus followed by Cladosporium, Penicillium, Alternaria, Fusarium, Curvularia, Trichoderma, and Rhizopus. Aspergillus niger, A. flavus, A. fumigatus, Penicillium spp. and Cladosporium herbarum, found to be dominant during the period of investigation. Important mycotoxin-producing fungi such as A. flavus, A. fumigatus and Fusarium moniliforme were isolated from the vegetables collected from the market.
\end{abstract}

Keywords: Bioaerosols, vegetable, saprophyte, pathogen, mycotoxin, post-harvest disease

\section{Introduction}

In many market places, spoiled material, dumped plant material and debris are often present and are likely to act as reservoirs of plant pathogens due to the constant build up of the spore population from fungi growing on them. The activity of nearly all fungi is to carry out biodegradation and deterioration because of their requirements for prime sources of carbon, nitrogen and other nutrients (PITT and HockING 1985). The deterioration of raw vegetables may also be caused by physical damage, the action of their own enzymes, microbial action or a combination of these factors.

* Corresponding address: B-12, Gagan Mahal, Sir Pochkhanwala Road, Worli, Mumbai, 400025, India, e-mail: drumeshkakde@gmail.com

Copyright ${ }^{\circledR} 2012$ by Acta Botanica Croatica, the Faculty of Science, University of Zagreb. All rights reserved. 
The spoilage occurring during the processing, distribution, and sale of fresh vegetables is often referred to as post-harvest spoilage or marketing disease. As a general rule, vegetables become more susceptible to infection by post-harvest pathogens as they ripen. Vegetable and fruits are perishable products with active metabolisms during the postharvest period (ECKERT 1975). Therefore, proper handling and environmental conditions after harvesting are essential in maintaining product quality. Mechanical damage has dual importance because it not only reduces the value of vegetables but an also increases the chance for microbial spoilage. Post-harvest diseases are responsible for significant loss of vegetable and fruit production (FRAZIER 1967).

A study of bio-aerosols in a market environment showed that most of the fungi found on vegetables and fruits originated in the field or developed during transportation (PANDURANJAN and SurYANARAYANAN 1985). Airborne spores can cause infection to salable articles. Although many types of microbial spoilage result from invasion by parasitic microorganism, much spoilage also results when normally saprophytic microorganisms behave as opportunistic parasites. For example tomatoes can be spoiled by members of the Fusarium and Geotrichum families (BRACKETT 1987). The spraying of water to give a fresh appearance to vegetables and fruits in the market also provides a moist surface that encourages the growth of molds in storages.

Bioaerosols in market environments may have some implications for the health of the people working in there. Most of the fungi present in high concentrations in market environments have been suspected of being causative agents of respiratory diseases in humans and infections of produce. The adverse effects of inhaled fungal propagules on the immune system have been well documented by various workers (DAY 1986; BURGE 1985, 1989; LACEY 1991).

Fungal infection can also increase the chances of contamination by mycotoxins, which can cause neurological disorders, liver cancers, lung cancers and other diseases. Many molds capable of producing mycotoxins are also frequent contaminants of food and agricultural commodities. Molds, which are of importance in food because of potential mycotoxin production, include members of the genera Aspergillus, Trichothecium, Fusarium. The mycotoxins that are currently receiving the most attention as potential hazards to human and animal health include aflatoxin, ochratoxin A, sterigmatocystin, patulin, penicillic acid, citrinin, zearalenone and the toxic trichothecenes. All these compounds cause some degree of acute toxicity when received in high amounts (KRAMER et al. 1960; HUDSON 1969; Willie and Morehouse 1978; Bullerman 1979; Wicklow and ShotTwell 1983; MiLler 1990, 1992).

No systematic studies on the incidence of post-harvest disease and airborne fungal spores in a vegetable market have been published. However, such information is needed to evaluate the relationship between the prevalence of fungal spores and post-harvest diseases of vegetables due to airborne fungi in markets, and to understand the type of mold exposure that can cause health effects. Hence, the present study was undertaken in one of the major vegetable markets of Nagpur city to investigate post-harvest disease due to the prevalence of airborne fungi in the market. In this paper we describe the measurement of airborne fungal spores and post-harvest diseases made in a vegetable market in Nagpur. 


\section{Material and methods}

The geographical location of Nagpur is 79 degrees 8 minutes east and 21 degrees 8 minute north. Thus it can be said that Nagpur falls in the Deccan plateau region. The city is located in Maharashtra State and lies in the center of India; the zero milestone of India is situated within this city. An aero-mycological survey was carried out in a vegetable market at Fule market $\left(21^{\circ} 8^{\prime} 45^{\prime \prime} \mathrm{N} / 79^{\circ} 55^{\prime} 26^{\prime} \mathrm{E}\right)$ in Nagpur city. It is one of the main outdoor vegetable markets of Nagpur City (M.S.), from which a number of vegetables are marketed and transported to different local and outstation markets. This market is situated in the heart of the city and surrounded on all sides by schools, quarters, gardens, railway station etc. The study was undertaken at different seasonal climatic conditions i.e., monsoon (June- September), winter (October-February) and summer (March-May) for the period of two years.

Bioaerosols were sampled using a rotorod air sampler and settle plates $(9 \mathrm{~cm}$ diameter Perti dishes) to provide quantitative and qualitative measurements of fungal spores respectively. The rotorod air sampler with a sampling rate of $100 \mathrm{~L} \mathrm{~min}^{-1}$ (Tilak Air Sampler, 1982) was used to analyze the total spore counts. The sampler was operated for $15 \mathrm{~min}$. at the height of one meter above the ground level at fifteen day intervals. The sampling was done during morning (07 am to $10 \mathrm{am}$ ) when the market was most active. Exposed cellophane tapes were mounted with glycerin jelly and examined under a microscope. The trapped spores were identified with the help of reference slides and available standard literature (AINSWORTH et al. 1972; TILAK 1982, 1989; NAIR et al. 1986).

For the qualitative analysis of fungi three different media were used: Czapek's Dox Agar (CZ), Potato Dextrose Agar (PDA) and Martin's Rose Bengal Agar (MRBA). Two Petri dishes of each medium were exposed for 3 minutes at intervals of 15 days during morning when market activities like loading unloading, agitation, weighing of vegetables were at their peak. All the Petri dishes were kept at different heights $(0.5-1 \mathrm{~m})$ above the ground. After exposure to the air the Petri dishes were brought to the laboratory in pre-sterilized polythene bags and incubated at $25^{\circ} \mathrm{C}$ for $5-7$ days. Colonies were counted and identified. The identification of colonies was based on their color, size, shape and other morphological features (GILMAN 1957, BARNETT 1960, RAPER and FENELL 1965, RAPER and Tном 1968, Sмiтн 1969, Ainsworth et al. 1972, Ellis 1971). The temperature and relative humidity of the air during the experiments were also recorded.

Samples of fresh as well as previously infected or rotten vegetables (cabbage, beans, onion, potato, tomato) were collected in pre-sterilized polythene bags from the same market to examine post-harvest fungi. For the growth of fungi, these vegetables were incubated using a sterile moist blotter method for 5 to 7 days. Fungi were isolated from these vegetable samples and observed directly by preparing lacto-phenol cotton blue mounts. Fungi isolated by this technique were sub-cultured to Sabouraud's agar and CZ medium and colonies grown for further identification up to species level.

\section{Results and discussion}

Quantitative and qualitative analysis of air samples showed that the market environment was contaminated by some major fungal spore types such as Aspergillus, Penicillium, Cladosporium, Alternaria. The spore population of fungi followed a definite seasonal 
variation in the weather prevailing over the market environment. The highest incidence of spores was observed during August to January (monsoon and winter) while March-May (summer) was the lean period.

\section{Quantitative and qualitative analysis of bioaerosols:}

Altogether 59 spore types and 78 fungal species were identified from the air of vegetable market by the rotorod sampler and settle plate method respectively. These belonged to 33 genera. Three spore types from the Zygomycotina, 13 from the Ascomycotina, 3 from the Basiodiomycotina and 30 from the Deuteromycotina were recovered by rotorod sampling. Unidentified, less frequent spore types, pollen grains and other bioerosols were classified as other types. Sixty-six species belonging to the class Deuteromycotina were identified from the settle plates, 10 from the Zygomycotina and 2 from the Ascomycotina. Unidentified colonies including yeasts and less frequent taxa were grouped as unidentified colonies (Tab. 1, 2).

More spore types and fungal species were found in the months of August, November and January than in April and May (summer). During the monsoon and winter seasons more varieties of vegetables and fruits are available in the market than at other time. The greater concentration of fungal spores during the winter and rainy seasons may be due to the greater availability of dead and decaying material in the market yard acting as sources

Tab. 1. Incidence of the dominant spore types collected in air samples in a vegetable market.

\begin{tabular}{lccc}
\hline Spore Types & Average spores $/ \mathrm{m}^{3}$ & Per cent contribution & Range $\left(\mathrm{spores} / \mathrm{m}^{3}\right)$ \\
\hline ASCOMYCOTINA & & & \\
Chaetomium & 24 & 0.7 & $0-85$ \\
BASIDIOMYCOTINA & & & \\
Smuts & 46 & 1.3 & $0-120$ \\
Uredospores & 32 & 0.9 & $0-95$ \\
DEUTEROMYCOTINA & & & \\
Alternaria & 464 & 13.2 & $120-800$ \\
Aspergillus/Penicillium $*$ & 1260 & 35.9 & $985-5200$ \\
Cercospora & 41 & 1.2 & $0-100$ \\
Cladosporium & 623 & 17.8 & $425-2000$ \\
Curvularia & 202 & 5.8 & $85-520$ \\
Drechslera & 40 & 1.1 & $0-95$ \\
Fusarium & 53 & 1.5 & $0-120$ \\
Helminthosporium & 126 & 3.6 & $10-300$ \\
Nigrospora & 65 & 1.9 & $0-150$ \\
Pithomyces & 24 & 0.7 & $0-95$ \\
Hyphal fragments & 54 & 1.5 & $20-150$ \\
Other Types\# & 456 & 13.0 & $125-900$ \\
\hline
\end{tabular}

* Small, spherical and similar type of spores, Aspergillus, Penicillium, Trichoderma, Mucor, Rhizopus. \# - less frequent, unidentified spores, pollen grains and other bioaerosols. 
Tab. 2. Incidence of the most common (contribution $>5 \%$ ) fungal species identified from settle plate samples in a vegetable market

\begin{tabular}{|c|c|c|c|c|c|}
\hline Fungal species & $\begin{array}{l}\text { Total } \\
\text { colonies }\end{array}$ & $\begin{array}{l}\text { Per cent } \\
\text { contri- } \\
\text { bution }\end{array}$ & Fungal species & $\begin{array}{c}\text { Total } \\
\text { colonies }\end{array}$ & $\begin{array}{c}\text { Per cent } \\
\text { contri- } \\
\text { bution }\end{array}$ \\
\hline \multicolumn{3}{|l|}{ ZYGOMYCOTINA } & C. lignicola & 160 & 3.2 \\
\hline Cunninghamella echinulata & 25 & 0.5 & Colletotrichum sp. & 61 & 1.2 \\
\hline C. elegans & 33 & 0.7 & Curvularia geniculata & 39 & 0.8 \\
\hline Mucor globosus & 27 & 0.5 & C. lunata & 117 & 2.3 \\
\hline Rhizomucor pusillus & 28 & 0.6 & C. oryzae & 55 & 1.1 \\
\hline Rhizopus oryzae & 25 & 0.5 & C. tetramera & 45 & 0.9 \\
\hline \multirow[t]{2}{*}{ R. stolonifer } & \multirow[t]{2}{*}{76} & \multirow[t]{2}{*}{1.5} & Drechslera australiensis & 42 & 0.8 \\
\hline & & & Fusarium chlamydosporum & 29 & 0.6 \\
\hline \multirow{2}{*}{$\begin{array}{l}\text { ASCOMYCOTINA } \\
\text { Chaetomium globosum }\end{array}$} & \multirow{3}{*}{26} & \multirow{3}{*}{0.5} & F. moniliforme & 140 & 2.8 \\
\hline & & & F. oxysporum & 47 & 0.9 \\
\hline DEUTEROMYCOTINA & & & F. solani & 136 & 2.7 \\
\hline Alternaria brassicae & 81 & 1.6 & Helminthosporium nodulosum & 45 & 0.9 \\
\hline A. solani & 112 & 2.2 & H. oryzae & 80 & 1.6 \\
\hline A. tenuis & 140 & 2.8 & Nigrospora sphaerica & 40 & 0.8 \\
\hline Aspergillus candidus & 129 & 2.6 & Penicillium citrinum & 131 & 2.6 \\
\hline A. flavipes & 38 & 0.8 & P. chrysogenum & 169 & 3.4 \\
\hline A. flavus & 258 & 5.1 & P. italicum & 104 & 2.1 \\
\hline A. fumigates & 126 & 2.5 & P. nigricans & 124 & 2.5 \\
\hline A. niger & 321 & 6.4 & P. oxalic & 40 & 0.8 \\
\hline A. ochraceous & 44 & 0.9 & Phoma lingam & 93 & 1.9 \\
\hline A. sydowi & 42 & 0.8 & Sporotrichum roseum & 36 & 0.7 \\
\hline A. terreus & 46 & 0.9 & Trichoderma harzianum & 76 & 1.5 \\
\hline A. versicolor & 25 & 0.5 & T. viride & 86 & 1.7 \\
\hline Botrytis cinerea & 25 & 0.5 & Trichothecium roseum & 25 & 0.5 \\
\hline Candida albicans & 33 & 0.7 & Verticillium glaucum & 25 & 0.5 \\
\hline Cladosporium epiphyllum & 215 & 4.3 & Sterile Colonies & 25 & 0.5 \\
\hline C. herbarum & 242 & 4.8 & Unidentified colonies* & 943 & 18.7 \\
\hline
\end{tabular}

(* Less frequent $(<.5 \%)$, unidentified colony forming units)

of inoculum. This coupled with moisture caused by dew in winter and rain in the monsoon, may promote profuse growth of fungi and subsequent sporulation and discharge of spores into the atmosphere.

In the two-year study Aspergillus-Penicillium type spores (small rounded) were the major spore type found, contributing $35.9 \%$ for the first year and $34.8 \%$ for the second year of the investigation to the total bioaerosols. Rest of the bioaerosols were made up of Cladosporium, Alternaria, Curvularia and Helminthosporium (Tab. 1).

Among the total counts of viable fungi identified, we recognized Aspergillus, Penicillium, Cladosporium, Alternaria and Curvularia as the most abundant genera. Aspergillus 
species were the most prevalent throughout the seasons. The most dominant species isolated were Aspergillus niger, A. flavus, A. fumigatus, Alternaria solani, Cladosporium herbarum, Curvularia lunata, Rhizopus stolonifer, Penicillium chrysogenum, P. italicum. The majority of these fungal species were present throughout the year. Aspergillus species followed a seasonal trend. Meteorological conditions such as high temperature and low humidity during the summer contribute fewer fungi while in the rainy season the concentration of fungi is significantly increased in the atmosphere of market. High concentrations of these fungal spores have been reported in different working environments (SUMBALI and BADYAl 1991, Sulia and Khan 1980, Rosas et al. 1992, KAKDE et al. 2001).

Spores of some fungi (Aspergillus, Penicillium, Cladosporium etc.) become airborne as a consequence of active liberation mechanism or more often in working environments by agitation of their substrates (INGOLD 1971). Handling of unwashed vegetables was responsible for the increase of the spore load concentration in the air especially of Cladosporium and Penicillium (LeHTONEN et al. 1993). These genera were also isolated from the surface samples of vegetables.

The seasonal pattern of Aspergillus, Cladosporium, Penicillium, Alternaria and other dominant fungi are governed by the availability of dead and decaying organic matter and their prevalence throughout the year was because of abundant substrata available for their growth in all the seasons in the market. In the present investigation variation in the spore concentrations was recorded in the different months (Fig. 1). The difference in the spore concentration and types could be due to the prevailing environmental conditions and presence of agricultural waste, plant debris and infected vegetables and fruits in the market environments. The release of fungal spores and consequently their concentrations in the atmosphere are the result of the action of many biological and environmental factors. The occurrence of fungal spores in the air is markedly seasonal because of these organisms' sensitivity to weather changes (HJElmroos 1993, Craig and Levetin 2000, StePalska and WOLEK 2005).

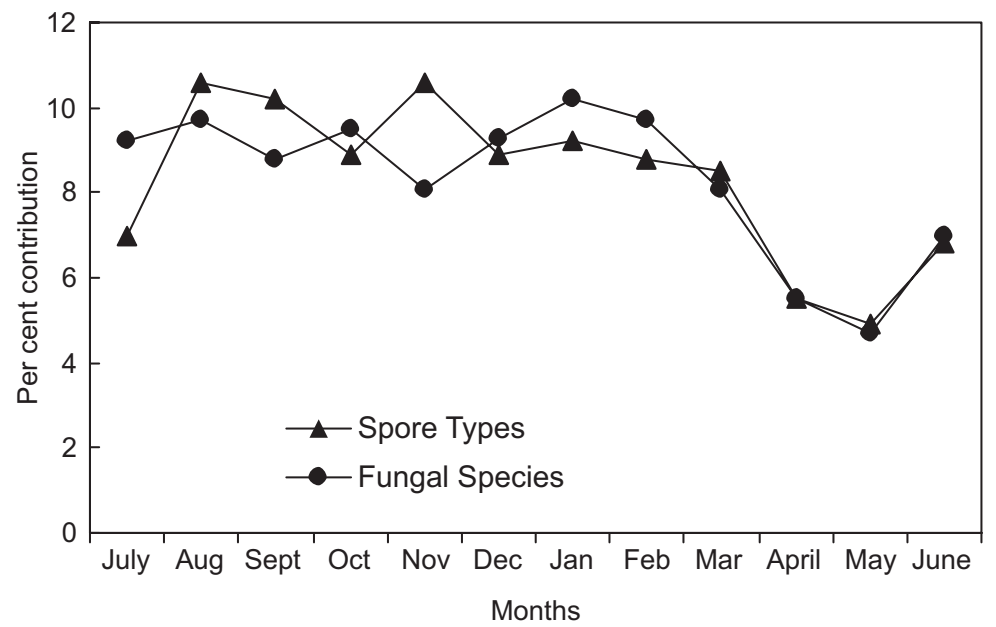

Fig. 1. Seasonal distribution of fungal spores and species during the sampling period in a vegetable market yard. 
Altogether forty-six fungi from 26 genera were isolated from selected common vegetables collected. There were 5 Zygomycotina species; one Ascomycotina and the rest of the species were Deuteromycotina. The largest number of species (46) was found on cabbage and cauliflower, 27 on tomato, 26 on bean, 24 on potato, and 15 on onion (Tab. 3). Some of the species found are presented in figure 2.

Tab. 3. Fungi isolated from different vegetables collected from a vegetable market

\begin{tabular}{|c|c|}
\hline Vegetables & Major fungal species associated \\
\hline $\begin{array}{l}\text { Cabbage } \\
\text { (Brassica } \\
\text { oleracia) }\end{array}$ & $\begin{array}{l}\text { Aspergillus niger, A. fumigatus, A. versicolor, A. flavus, Alternaria brassicae, } \\
\text { A. alternata, A. solani, Botrytis cinerea, Cercospora brassicae, Cladosporium } \\
\text { herbarum, Curvularia lunata, Fusarium brassicae, F. moniliforme, Penicillium } \\
\text { chrysogenum, Phoma brassicae, Phoma lingam, Rhizopus sp., Trichoderma } \\
\text { herzianum, T. viride }\end{array}$ \\
\hline $\begin{array}{l}\text { Bean } \\
(\text { Dolichos } \\
\text { lablab) }\end{array}$ & $\begin{array}{l}\text { Aspergillus niger, A. flavus, A. fumigatus, Alternaria solani, A. brassicae, } \\
\text { Botrytis cinerea, Cladosporium species, Fusarium spp., Rhizopus sp., } \\
\text { Penicillium crysogenum, Penicillium species, }\end{array}$ \\
\hline $\begin{array}{l}\text { Onion } \\
\text { (Allium cepa) }\end{array}$ & $\begin{array}{l}\text { Alternaria tenuis, A. solani, Aspergillus niger, A. flavus, Botrytis cinerea, } \\
\text { Cladosporium herbarum, Colletotrichum sp., Fusarium moniliforme, } \\
\text { Rhizopus sp., Penicillium digitatum, Trichoderma spp. }\end{array}$ \\
\hline $\begin{array}{l}\text { Potato } \\
\text { (Solanum } \\
\text { tuberosum) }\end{array}$ & $\begin{array}{l}\text { Aspergillus niger, A. flavus, Alternaria brassicae, A. solani, A alternata, } \\
\text { Botrytis cinera, Cercospora brassicae, Cladosporium herbarum, Curvularia } \\
\text { lunata, Fusarium spp., F. moniliforme, Rhizopus stolonifer, Penicillium } \\
\text { chrysogenum, Phoma lingam, Rhizoctonia solani, Trichoderma herzianum }\end{array}$ \\
\hline $\begin{array}{l}\text { Tomato } \\
\text { (Lycopersicon } \\
\text { esculentum) }\end{array}$ & $\begin{array}{l}\text { Aspergillus niger, A. flavus, Alternaria alternata, A. solani, Botrytis cinera, } \\
\text { Cladosporium herbarum, Cladosporium sp., Colletotrichum sp., Fusarium } \\
\text { moniliforme, Fusarium solani, Rhizopus stolonifer, Penicillium chrysogenum, } \\
\text { Saccharomyces sp. }\end{array}$ \\
\hline
\end{tabular}

In the present investigation a few more fungal species were isolated from the air during August, November, December and January (Fig. 1). The incidence of post-harvest diseases in the vegetables was also higher than in other months. As the concentration of fungal spores in the air decreases, the frequency of occurrence of fungi on the vegetables also decreases, and vice-versa. Aspergillus species were found to be the chief contaminant from the total species isolated. The most frequently isolated fungal species from vegetables were Aspergillus niger, A. flavus, Penicillium crysogenum, Curvularia spp., Cladosporiun herbarum, Rhizopus stolonifer, Alternaria spp., Fusarium spp. Aspergillus has been reported as the dominant spore type in markets and other environments by many researchers (Sullia and KHAN 1980, PANDURAJAN and SuRryANARAYANAN 1985, SANTRA and ChANDA 1989, AbDEl-Hafez et al. 1989, Sumbali and BAdyal 1991, Duchaine et al. 2001, KAKDE et al. 2001).

In the last few years it has been reported that the spores and sclerotia of toxic fungi contain very large concentrations of mycotoxins. The spores of Aspergillus flavus and A. parasiticus have been reported to contain $1100 \mu \mathrm{g} \mathrm{g}^{-1}$ of aflatoxin, which is carcinogenic to human beings (WICKLOW and SHOTWELL 1983). 
KAKDE U. B., KAKDE H. U.
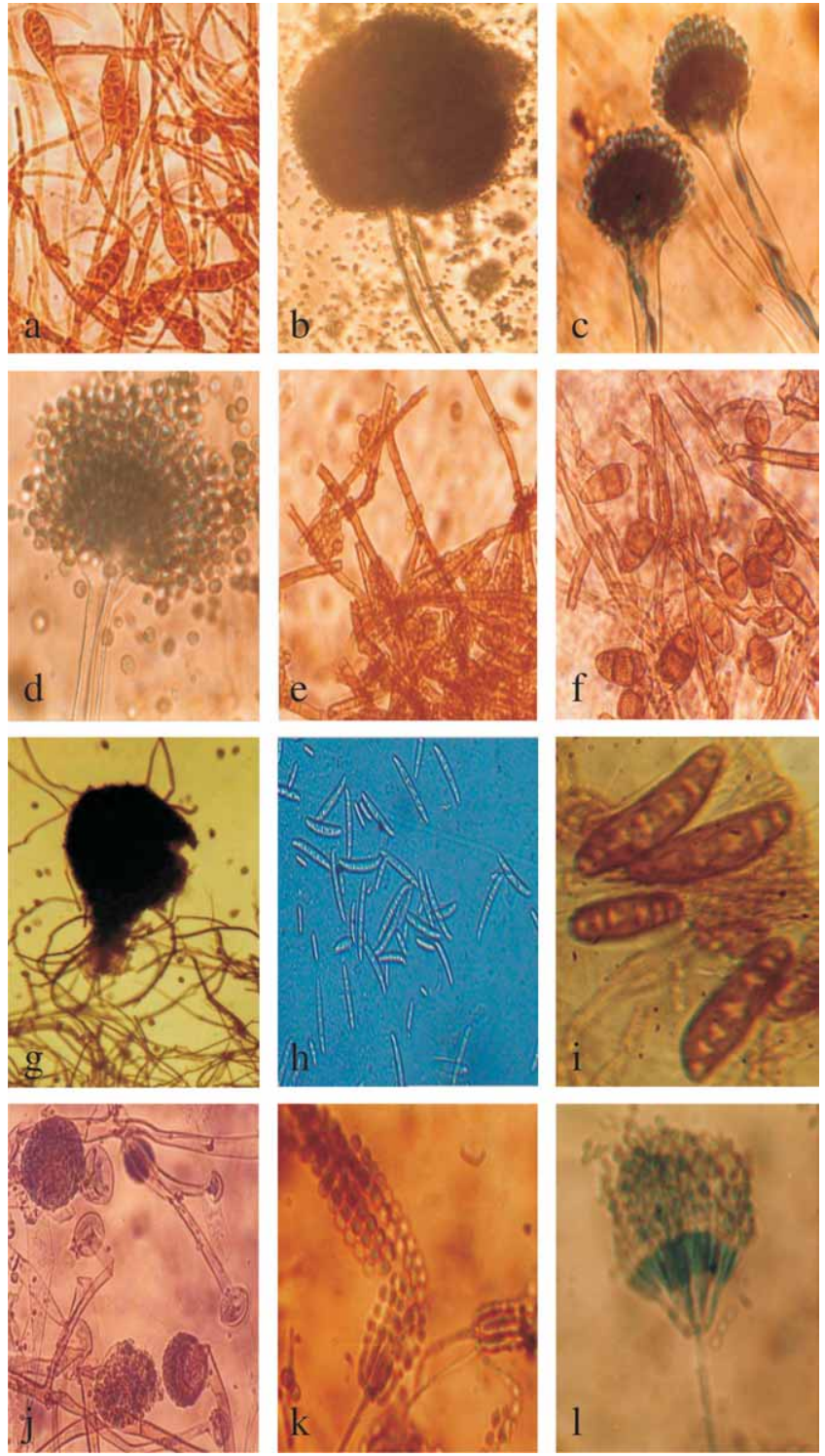

Fig. 2. Some common fungi isolated from the vegetables collected from the market: a - Alternaria solani, $\mathrm{b}$ - Aspergillus niger, $\mathrm{c}-$ Aspergillus flavus, $\mathrm{d}$ - Aspergillus fumigatus, e - Cladosporium herbarum, f - Curvularia lunata, g - Chaetomium gobosum, h - Fusarium moniliforme, i - Helminthosporium orza, $\mathrm{j}$ - Rhizopus $\mathrm{sp}, \mathrm{k}$ - Penicillium citrinum, 1 Penicillium chrysogenum

A series of experiments on fungal species isolated both from vegetables and air were carried out. One such experiment reported the correlation coefficient $(r)$ between percent occurrence of 15 fungal species on selected vegetables $(x)$ and percent occurrence in air $(y)$ as 0.7595 . This indicates a strong positive linear dependence between $x$ and $y$. 
Can it be concluded that, in the population of these fungal species, the population correlation coefficient, $\rho=0.50$ is significant? The problem in this situation is to test the null hypothesis $H_{0}: \rho=0.50$ against the alternative hypothesis $H_{0}: \rho \neq 0.50$.

We are given $n=15, r=0.7595$ and $\rho_{0}=0.50$.

$$
\begin{gathered}
Z=\frac{1}{2} \log _{e}\left[\frac{1+r}{1-r}\right]=\frac{1}{2} \log _{e}\left[\frac{1+0.795}{1-0.795}\right]=0.9950 \\
W=\frac{1}{2} \log _{e}\left[\frac{1+\rho_{0}}{1-\rho_{0}}\right]=\frac{1}{2} \log _{e}\left[\frac{1+0.50}{1-0.50}\right]=0.5493 \\
T=(Z-W) \cdot \sqrt{n-3}=(0.9950-0.5493) \cdot \sqrt{12}=1.5440
\end{gathered}
$$

The table value at $5 \%$ level of significance is 1.96 .

Since, $|T|<1.96$, we accept $H_{0}$ at the $5 \%$ level of significance and conclude that the data support the hypothesis.

Hence, using information on the percentage isolation of fungal species on vegetables, the percentage isolation in air can be predicted.

\section{Conclusion}

The most frequent associated fungi isolated from the vegetable and fruits were Aspergillus niger, A. flavus, Penicillium crysogenum, Curvularia spp., Alternaria spp., Fusarium spp. Aspergillus, Penicillium, Cladosporium, Fusarium, Alternaria etc. These fungi were most prevalent in the air of market environment and also found to be responsible for most of the decay of the vegetables during storage. Hence, there is probably a cyclic relationship existing between the prevalence of fungal bioaerosols and spoilage diseases in market environments. That may be due to the growth of fungi on dumped plant materials, packing leaves, infected vegetables and fruits, where fungi grow saprophytically and produce spores profusely, consequently contaminating the environment. There was a good correlation between the number of visible mold growths on collected vegetables from the market and the concentration of airborne molds in the market environment. Although there were fewer fungal species in the air, all the dominant fungal spores recovered from the air were also isolated from the samples of vegetables collected.

Hence, both air and surface sampling are necessary to evaluate mold problems in such environments. The number of mold growths on salable articles is a good predictor of airborne mold concentration.

\section{References}

Abdel-Hafez, S. I. I., El-SAID, A. H. M., 1989: Seasonal variation of airborne fungi in Wadi Quena, Eastern Desert, Egypt. Grana 28, 193-203.

Ainsworth, G. C., Sparrow, F. K., Sussman, A. S., 1972: The fungi, 4 A. Academic Press, New York. 
BARnETT, H. L., 1960: Illustrated genera of imperfect fungi. Burgess Publishing Co. Minneapolis.

BRACKETT, R. E., 1987: Vegetables and related products. In: BEUCHAT, L. R. (ed.), Food and beverage mycology, 129-154. Van Nostrand Reinhold, New York,

Bullerman, L. B., 1979: Significance of mycotoxins to food safety and human health. Journal of Food Protection 42, 65-86.

Burge, H. A., 1985: Fungus allergens. Clinical Reviews in Allergy 3, 319-229.

Burge, H. A., 1989: Airborne allergenic fungi: classification, nomenclature, and distribution. Immunology and Allergy Clinics of North America 9, 307-319.

Craig, R. L., Levetin, E., 2000: Multi-year study of Ganoderma aerobiology. Aerobiologia 16, 75-81.

DAY, J. H., 1986: UFEI-Fungal interaction-working paper provided to the health and welfare Canada. Ottawa, Ontario, K1AOL2.

Duchaine, C., MeriauX, A., 2001: The importance of combining air sampling and surface analysis when studying problematic houses for mold biodiversity determination. Aerobiologia 17, 121-125.

ECKert, J. W., 1975: General principles, 1. In: PANTASTICA, E. B. (ed.), Post-harvest physiology, handling and utilization of tropical and subtropical fruits and vegetables, 393414. AVI Publishing Co., Westport.

Ellis, M. B., 1971: Dematiaceous Hyphomycetes. Publisher Commonwealth Agricultural Bureaux. Commonwealth Mycological Institute. Kew, Surrey (UK).

FrazIER, W. C., 1967: Food Microbiology. McGraw-Hill Book Co., Inc, New York.

Gilman, J. C., 1957: A manual of soil fungi. IOWA State Uni. Press. Ames.

HJelmroos, M., 1993: Relationship between airborne fungal spore presence and weather variables. Grana 32, 40-47.

Hudson, H. J., 1969: Aspergilli in the airspora at Cambridge. Transactions British Mycological Society 52, $153-159$.

IngOLD, C. T., 1971: Fungus spores: Their liberation and dispersal. Oxford University Press, London and New York.

KaKde Umesh, B., KaKde Hemalata, U., Saoji Aarti, A., 2001: Seasonal variation of fungal propagules in a fruit market environment, Nagpur (India). Aerobiologia 17, 177182.

Kramer, C. L., Pady, S. M., Rogerson, C. T., 1960: Kansas aeromycology, 5. Penicillium and Aspergillus. Mycologia 52, 545-551.

LACEY, J., 1991: Aerobiology and health the role of airborne fungal spores in respiratory disease In: Hawks Worth, P. L. (ed.), Frontiers in mycology. C.A.B. International, Kew.

LeHtonen, M., Reponen, T., 1993: Everyday activities and variation of fungal spore concentration in indoor air. International Journal of Biodeterioration and Biodegradation $31,25-39$.

Miller, J. D., 1990: Contamination of food by Fusarium toxin studies from Austria-Asia Proceeding. Japanese Association of Mycotoxicology 32, 17-24. 
Miller, J. D., 1992: Fungi contaminants in Indoor air. Atmospheric Environment 26 A, 2163-2172.

Nair, P. K. K., Joshi, A. P., Gangal, S. V., 1986: Airborne pollen spores and other plant materials of India. CSIRO Centre Biochemicals, Delhi and Lucknow.

Pandurajan, A. G., Surryanarayanan, J., 1985: A survey of mycoflora associated with some fresh vegetable and fruits in a market at Saidpeth market. Journal of Economic and Taxonomic Botany 7, 309-315.

PitT, J. I., Hocking, A. D., 1985: Fungi and food spoilage. Academic Press, Sidney, Australia.

RAPER, K. B., FEnNELl, D. I., 1965: The genus Aspergillus. The Williams and Wilkins Co., Baltimore.

Raper, K. B., Thom, C., 1968: A manual of Penicillia. Hafner Publishing Co., New York.

Rosas, I., Calderon, C., Escamilla, B., Ulloa, M., 1992: Seasonal distribution of Aspergillus in the air of an urban area: Mexico City. Grana 31, 315-319.

SANTRA, S. C., Sunirmal Chanda, 1989: Airborne fungal flora in indoor environment of the Calcutta Metropolis, India. Grana 28, 141-145.

SMith, G., 1969: An introduction to industrial mycology. Edward Arnold Ltd, London.

STEPALSKA, D., WOLEK, J., 2005: Variation in fungal spore concentrations of selected taxa associated to weather conditions in Cracow, Poland, in 1997. Aerobiologia 21, 43-52.

SuliA, S. B., KHAN, K. R., 1980: Aerospora of Bangalore city market and its relation to occurrence of market diseases. Journal Advances in Pollen and Spore Research 5-7, $157-159$.

Sumbali, G., Badyal, K., 1991: Relationship between fungal aerospora of fruit shop and incidence of fruit rots. Journal Indian Phytopath 44, 214-218.

TILAK, S. T., 1982: Aerobiology. Vaijayanti Prakashan, 'Ushakal' Saraswati Colony, (West) Aurangabad.

TILAK, S. T., 1989: Airborne pollen and fungal spores. Vaijayanti Prakashan, Aurangabad.

Wicklow, D. T., ShotTwell, O. L., 1983: Intra-fungal distribution of aflatoxin among conidia and sclerotia of Aspergillus flavus and A. parasiticus. Canadian Journal of Microbiology 29, 1-5.

Willie, T. D., Morehouse, L. G., 1978: Mycotoxic fungi, mycotoxins, and mycotoxicosis. Mareal Dekkar Inc., New York. 